\title{
Analysis of Thermovisual Data of the Radio-Frequency Impact on the Myocardium Damage
}

\author{
Vincentas VEIKUTIS ${ }^{1}$, Gintautas DZEMYDA ${ }^{2}$, Povilas TREIGYS ${ }^{2}$, \\ Kristina MORKŪNAITÉ ${ }^{3}$, Algidas BASEVIČIUS ${ }^{4}$, \\ Saulius LUKOŠEVIČIUS ${ }^{4}$, Gintare ŠAKALYTE ${ }^{5}$, \\ Antanas SEDEREVIČIUS ${ }^{6}$ \\ ${ }^{1}$ Institute for Biomedical Research of Kaunas University of Medicine \\ Eiveniu 4, LT-3007 Kaunas, Lithuania \\ ${ }^{2}$ Institute of Mathematics and Informatics \\ Akademijos 4, LT-08663 Vilnius, Lithuania \\ ${ }^{3}$ Institute of Cardiology of Kaunas University of Medicine \\ Eiveniu 4, LT-3007 Kaunas, Lithuania \\ ${ }^{4}$ Department of Radiology of Kaunas University of Medicine \\ Eiveniu 2, LT-3007 Kaunas, Lithuania \\ ${ }^{5}$ Department of Cardiology of Kaunas University of Medicine \\ Eiveniu 2, LT-3007 Kaunas, Lithuania \\ ${ }^{6}$ Lithuanian Veterinary Academy \\ Tilžès 18, LT-471813 Kaunas, Lithuania \\ e-mail:treigys@ktl.mii.lt
}

Received: January 2010; accepted: August 2010

\begin{abstract}
In this article, a method is proposed for analysing the thermovision-based video data that characterize the dynamics of temperature anisotropy of the heart tissue in a spatial domain. Many cardiac rhythm disturbances at present time are treated by applying destructive energy sources. One of the most common source and the related methodology is to use radio-frequency ablation procedure. However, the rate of the risk of complications including arrhythmia recurrence remains enough high. The drawback of the methodology used is that the suchlike destruction procedure cannot be monitored by visual spectra and results in the inability to control the ablation efficiency. To the end of understanding the nature of possible complications and controlling the treating process, the means of thermovision could be used. The aim of the study was to analyse possible mechanisms of these complications, measure and determine optimal radio-frequency ablation parameters, according to the analysis of video data, acquired using thermovision.
\end{abstract}

Keywords: data mining, image analysis, morphological processing, clustering, thermovision, myocardium damage, radio-frequency ablation. 


\section{Introduction}

In this article, the investigation of thermovisual data is carried out with a view to identify the thermal anisotropy dynamics in different heart tissues that are under the sway of radio-frequency $(\mathrm{RF})$ ablation procedure. Thermovision allows us to monitor temperature changes: it produces some video data that characterize the dynamics of temperature in a spatial domain. The visual data require special analysis methods that cover both complex computations and medical interpretation. The article is devoted to the analysis of radiofrequency ablation procedure parameters such as RF impulse current energy power and lesion time with respect to temperature changes in the heart tissue surface. This, in turn, could explain the mechanisms and range of the risk of post-ablation complications. The method proposed relies on the analysis of colour systems, mathematical morphological processing, and the binarization result, based on the clustering method (Treigys, 2010).

In more than 20 years of clinical experience, RF ablation and cryo-destruction have been in standard use to correct many cardiac arrhythmias. Unfortunately, in spite of using modern RF ablation technologies, there is an enough high rate of post-operative complications, such as huge thrombogenesis, endocardial lesions, perforation rate (Aupperle et al., 2005), and according to the literature it reaches 14\% (Jais et al., 2004; Ouyang et al., 2004; Tan et al., 2009). Usages of cryo-energy until now become technically complicated. Consequently, efficacy must be balance against the safety and possibly potential complications.

The tissue impact of temperature, particularly hyperthermia, depends on the energy power, application time, and tissue characteristics. Repartition and spread of heat is not even and highly depends on the tissue and surrounding tissue structure and characteristics. Repartition of temperature is not only a result of energy absorption, but is also influenced by tissue physical characteristics and body fluid circulation. It was been stated that cells of a healthy tissue are not damaged when heated at temperature of $44^{\circ} \mathrm{C}$ for one hour, but later it has been observed that various tissues react differently. Neural system's tissues are most sensitive to temperature variations. Irreversible damages of tissues of the central neural system were observed after heating them at $42-42.5^{\circ} \mathrm{C}$ temperature for 40-60 min (Sminia et al., 1994). Longer than $30 \mathrm{~min}$ heating causes temporal function loss in the peripheral neural system, and after four weeks the function comes back (Wondergem et al., 1988). There are some opinions that prescribing hyperthermia to patients, who have cardiovascular diseases, should be limited, because the cardiovascular system is sensitive to heating (Sminia et al., 1994). The major cause of death in hyperthermia is arrhythmias (Chien, 2000; Steenland, 1996). In addition, the heating stress causes a rough and irreversible damage to cardiomiocytes (Qian et al., 1999; Sminia et al., 1994; Song et al., 2000). It seems that temperature damage made by RF ablation affects the contractile myocardium, the status and function of subepicardial neural structures, responsible for vagosympathetic rhythm regulation. There are not many data about RF energy produced temperature propagation in different heart tissues and in fact, we have not found any complex studies with the use of thermovision methods in literature (Dzemyda et al., 2008). 
According to Tan et al. (2009) a successful treatment of atria fibrillation by the catheter ablation procedure does not surpass $60 \%$. A worthy remark that RF ablation procedure in the heart areas with high density of vagosympathetic innervations often determines various grade sinoatrial and atrioventricular blocks, and often leads to difficult correction of supraventricular and ventricular tachycardia (Berruezo et al., 2007; Dzemyda et al., 2008; Ouyang et al., 2004; Pappone et al., 2001). In medical practice treatment, capabilities have expanded almost to the whole area of the cardiac texture zones. However, the reasons of these post ablative complications are not analysed and usually the comments contain only technical achievements of electrode positioning equipment, properties of ablative electrodes, electro-anatomical mapping systems, and sometimes clinical personnel experience. The aim of our study is to analyse possible mechanisms of these complications, to measure and determine optimal RF ablation parameters that perform endocardial destructive actions in heart. In order to understand the nature of possible complications, the technique of thermovisual monitoring can be introduced. It offers a possibility to use a wide range of analysis methods in terms of video or image processing.

Thermography is a non-invasive contact free method allowing assessment of changes of body surface temperature in real time. At first, a thermovision camera records the emitted infrared radiation; therewith recorded radiation after digital processing is presented in the form of a thermogram on the screen of PC or TV. Thermography in Lithuania firstly used in experimental and cardiovascular surgery practice to investigate the myocardium and coronary artery function. Unlike other methods of visualization, thermography can be easy applied without requiring special precautions of foreign contrast agents, and it renders the heart free for surgical procedures throughout the imaging process. Real-time scanning at standard video rates allows to see rapid, thermally transient events after cardioplegia, gives an opportunity to visualize temperature dynamics on the beating heart and by this assess myocardium and grafts function. When performing a coronary bypass without artificial blood circulation, it is important to be aware of how a suspension of the blood flow affects the myocardium and restoration of coronary blood flow after surgery. Diagnosis and treatment of the ischemic disease are the most important problems in cardiology. In many cases, a sudden death is caused by myocardial ischemia and is accompanied by ventricular arrhythmias. It has been proved that ischemic slowdown of excitation spread provokes the formation of recurrence of arrhythmia, ventricular tachycardia and ventricular fibrillation (Lekas et al., 2009). During coronary artery bypass grafting operations a surgeon requires information regarding the coronary flow, coronary anatomy, and myocardial perfusion. Additional quantitative flow estimation is desirable to detect graft failures as early as possible (Mačiulis et al., 2009). Some pictures taken from the thermovisual video stream are presented in Fig. 1.

The pilot research (Dzemyda et al., 2008) has proved that the thermovisual data are rather promising for estimating the heart state. In addition, these results have shown the necessity to extend the research. The aim is to investigate the dependency parameters of the radio-frequency ablation procedure by registering the dynamics of absorption and spread of heat on various cardiac structures over a certain time in a thermovisual video 

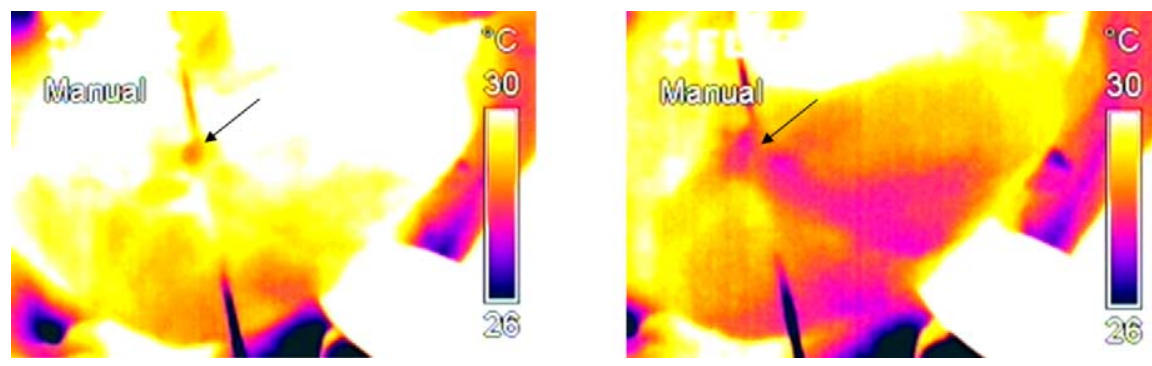

Fig. 1. Artery occlusion location (left-hand side), spreading of cold across the left ventricular wall (right-hand side).

stream. Thus, by incorporating the methods of mathematical morphology and clustering, we can approximate the thermal anisotropy zone. Moreover, that enables us automatically identify, register, and track the changes in the structure as well as to evaluate the dynamics in time of the affected zone. In this article, we will disclose the dependency of the area of the affected zone on the energy and time of the radio-frequency ablation procedure.

\section{Analysis of Colour Systems}

In order to disclose the affected zone, an overview of the colour systems will be accomplished. In general, colour, which a human understands, is the brain reaction to a visual stimulus. The precise colour description can be achieved by measuring the spectral power distribution of electromagnetic waves. However, in the case of human vision, it falls into redundancy. This is related to a human perception of the colour. The human eye roughly has three types of cones, which can perceive a red, green, and blue light (Shanker, 2001). Moreover, by transmitting a signal to the brain together with the signals received by rods that measure the intensity, we are able to perceive colour. Later, a colour space can be defined. A colour space or model is nothing more than a method for creation, specification, and visualization of a colour (Hunt and Horwood, 1998). Hence, there is a lot of colour systems which are different and can be efficiently used in different applications. The CIE has defined (Rencz, 1999) a system that classifies colours according to the human visual system. Using this system, we can specify any colour in terms of its CIE coordinates and hence be confident that a CIE defined colour will match another of the same CIE definition. In the sequel, a short description of colour systems will be provided.

RGB (Red, Green, Blue) is an additive colour system, based on the tri-chromatic theory (Rencz, 1999). Despite the fact that the RGB colour system is easy to implement, however it is nonlinear with a visual perception and is semi-intuitive. The CMYK (Cyan, Magenta, Yellow, Black) colour system is a subtractive colour system. This system is also nonlinear with a visual perception. Component $K$ (Black) is introduced to improve the density and the available gamut of colours. Lab(CIEL $a b)$ is a spherical colour system and is considered to be perceptually uniform and nearly uniform with a visual perception (Russ, 2006; Jiying et al., 2010). It is related to the fact that this colour system is based 
on the CIE system of colour measurement, which is based on the human vision, where $L$ is a gray-scale axis or luminance, while $a$ and $b$ are two orthogonal axes that define the colour and saturation. $a$ axis runs from red to green and $b$ axis runs from yellow to blue.

In order to better identify the problem domain area, a characteristic such as the image intensity distribution, has been visualized for different colour systems (Fig. 2). The first row shows the $R, G$, and $B$ channel histogram of pixel intensities, the middle line $L, a$, and $b$ channel pixel intensity histogram, and the lowest one represents $C, M, Y$, and $K$ channel pixel intensity histograms.

Figure 2 shows the histograms of pixel intensities of different colour system channels. On the abscise axis, the pixel intensity levels are shown. The intensity of the charts (middle line $a$ and lower line $M$ ) forms two classes of peaks, with different intensity densities. One of the equivalence classes is the heated area, and the other represents the background.
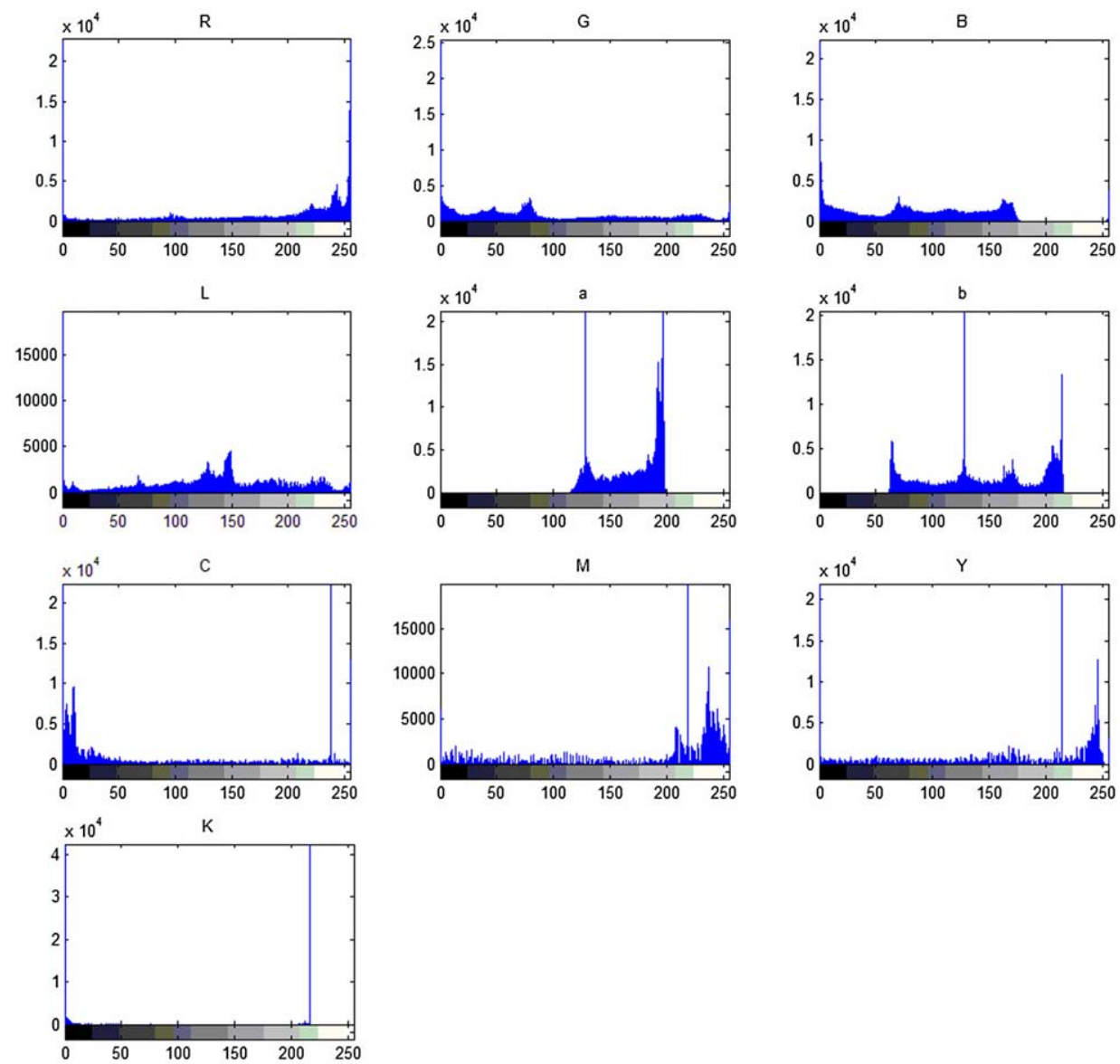

Fig. 2. Intensity distribution histograms of the colour systems channels. First row represents RGB, second row $\mathrm{L} a b$, and two bottom rows CMYK colour system channels. 

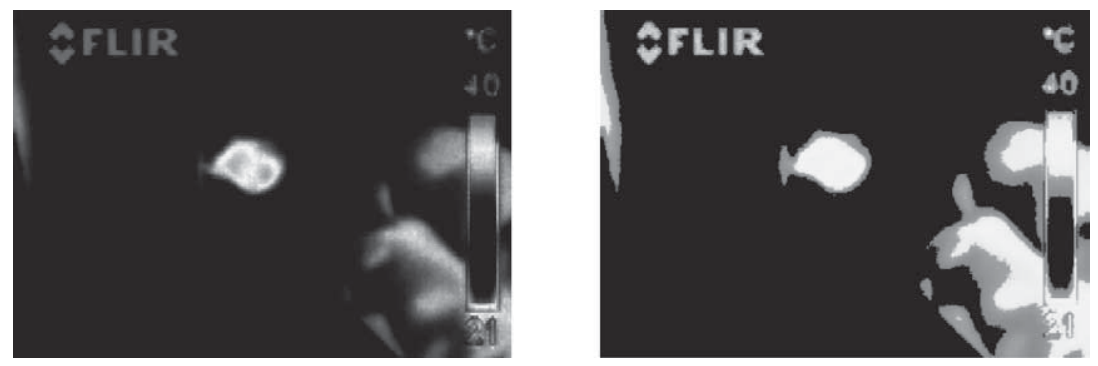

Fig. 3. Results in the $a$ colour channel (left-hand side) and in the $M$ colour channel (right-hand side).

Further, by applying Eq. (1) to histogram equalization:

$$
\max \left(0, \text { round }\left[D \frac{p_{k}}{n m}\right]\right) \text {, }
$$

we achieve a flattened histogram of pixel intensities, where $D=255, n$ is the height of the video frame in pixels, $m$ is the width of the video frame in pixels, and $p_{k}$ is the sum of pixels the intensity level of which is $k$ or lower.

The achieved results are visualized in the spatial domain in Fig. 3.

\section{Segregation of the Anisotropy Zone}

In order to identify the objects, they must be segregated. Segregation is commonly accomplished by converting the intensity image into a black-and-white one using threshold level. However, this task is not so easy to implement. Basically, a problem arises in the context of different circumstances depending on which video was made. The analogous situation where the threshold level was not known for each frame, the Otsu method was quite useful (Treigys et al., 2008). Then, for the anisotropy zone segregation, the video stream was cut into frames the histogram equalization was applied (1) to each frame. Further, for each frame the threshold level $\tau$ was calculated automatically:

$$
\sigma_{B}^{2}(\tau)=\omega(\tau)(1-\omega(\tau))\left(\mu_{1}(\tau)-\mu_{2}(\tau)\right)^{2},
$$

where

$$
\omega(\tau)=\sum_{i=0}^{\tau} \frac{n_{i}}{n m} \mu_{1}(\tau)=\sum_{i=0}^{\tau} \frac{n_{i}}{n m} \mu_{2}(\tau)=\sum_{i=\tau}^{L-1} i \frac{n_{i}}{n m} .
$$

The optimal threshold is found by the Otsu method through a sequential search for the maximum $\max _{0 \leqslant \tau<L} \sigma_{B}^{2}(\tau)$ of $\tau$, where $n_{i}$ represents the number of pixels at the intensity $i$, and $L$ is the number of intensities (Tian et al., 2003).

Afterwards, mathematical morphology processing was introduced in order to clear the objects in contact with the perimeter of the frame. This happens when the physician's 


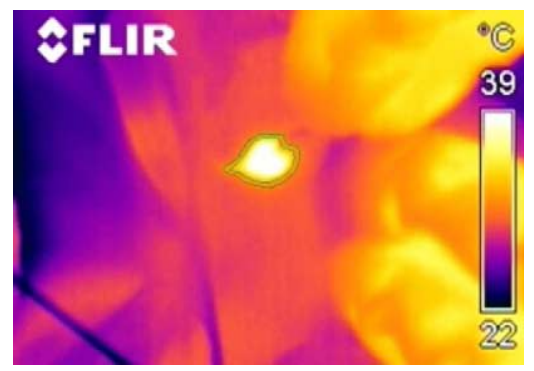

Fig. 4. Segmented heated zone.

hand acts closer to a microbolometer than the tissue being filmed. This results in a greater emission of heat registered by the thermovision camera as well as in an anisotropy zone localization error. Further, the closing operation of mathematical morphology was used (3) to fill the dark holes of the heated zone resulting after the threshold operation:

$$
\min _{(i, j) \in Z}\left(\max _{(i, j) \in Z}\left(l_{x+i, y+j}\right)\right)
$$

Here $I$ is a video frame, $Z$ is a structuring element, $i$ and $j$ are indices of the pixel of $z, x$ and $y$ points to frame pixel that is under procession (Treigys, 2010). In this investigation, a disc-shaped structuring element of six-pixel diameter was used.

Finally, the zone perimeter marker was put around the segmented anisotropy zone (Fig. 4).

Figure 4 represents the heated zone that was segmented automatically. A double line around the heated area is due to the fact that the segmentation was performed using two colour systems. In order to evaluate the dynamics of the heated area, the temperature range was fixed on the thermal camera. If the temperature range was not fixed, we only could evaluate the temperature dynamics with respect to the fixed anisotropy zone, but not the area dynamics with respect to the changing temperature.

\section{Investigation of the Anisotropy Zone Dynamics}

The lesions were experimentally assessed on the pulmonary vein and right-left atrium free wall zones with different features of the experimental conditions. Both the pulmonary vein and atrium were exposed to epicardial and endocardial electrodes of different impulse current power and different lesion time.

Experiments were performed on eight unisex mongrel dogs of both sexes, according to the permission of the Lithuanian Committee for Ethics of Good Laboratory Animal Use Practice (No. 0053/2005) by standard procedure protocol (Lekas et al., 2009). A standard ECG leads (I, II, III), arterial blood pressure and blood saturation were monitored throughout the study. Standard $4 \mathrm{~mm}$ Biosense Webster ${ }^{\circledR}$ (Johnson \& Johnson, USA) electrodes were used. Destruction was performed using Prucka Engineering radiofrequency energy generator Osypka Hat ${ }^{\circledR}$ 200S. Video was taken with FLIR Systems 
Table 1

Experiment parameters of the pulmonary vein lesions

\begin{tabular}{lll}
\hline $\begin{array}{l}\text { Experiment } \\
\text { No. }\end{array}$ & $\begin{array}{l}\text { Impulse current power } \\
\text { of electrode }\end{array}$ & $\begin{array}{l}\text { Lesion } \\
\text { time }\end{array}$ \\
\hline 1 & $20 \mathrm{~W}$ & $10 \mathrm{~s}$ \\
2 & $20 \mathrm{~W}$ & $20 \mathrm{~s}$ \\
3 & $30 \mathrm{~W}$ & $10 \mathrm{~s}$ \\
4 & $30 \mathrm{~W}$ & $20 \mathrm{~s}$ \\
5 & $50 \mathrm{~W}$ & $10 \mathrm{~s}$ \\
6 & $50 \mathrm{~W}$ & $20 \mathrm{~s}$ \\
\hline
\end{tabular}

Table 2

Experiment parameters of the atrium lesions

\begin{tabular}{lll}
\hline $\begin{array}{l}\text { Experiment } \\
\text { No. }\end{array}$ & $\begin{array}{l}\text { Impulse current power } \\
\text { of electrode }\end{array}$ & $\begin{array}{l}\text { Lesion } \\
\text { time }\end{array}$ \\
\hline 1 & $20 \mathrm{~W}$ & $20 \mathrm{~s}$ \\
2 & $30 \mathrm{~W}$ & $20 \mathrm{~s}$ \\
3 & $50 \mathrm{~W}$ & $20 \mathrm{~s}$ \\
\hline
\end{tabular}
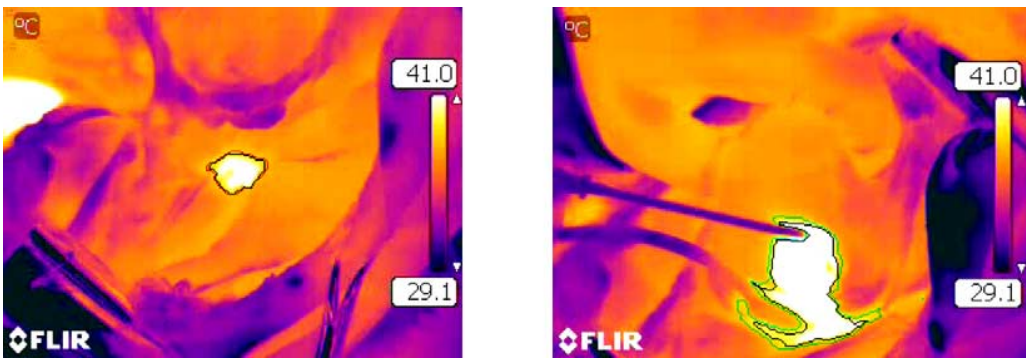

Fig. 5. Lesions of the pulmonary vein (left-hand side) and auricle of atrium (right-hand side).

thermovision camera ThermaCAM ${ }^{\circledR} T 400$. The method proposed was applied on iron colour palette and do not depend on the thermovisual camera.

The parameters that describe the experiment on pulmonary veins are presented in Table 1 and that on atrium in Table 2. All the experiments were carried out while the range of temperature recorded by the thermovision camera was fixed, namely, the range of $29-41{ }^{\circ} \mathrm{C}$. Further, the recorded footage was analysed. The analysis covered the tissue reaction to lesion. Some individual frames from the video footage with the approximated lesion are provided in Fig. 5.

As shown in Fig. 5, lesions in the different tissue sites are different. Moreover, since all the experiments were filmed by a thermovision camera, it became possible to analyse the dynamics of the anisotropy zone referring to the electrode impulse current power and 


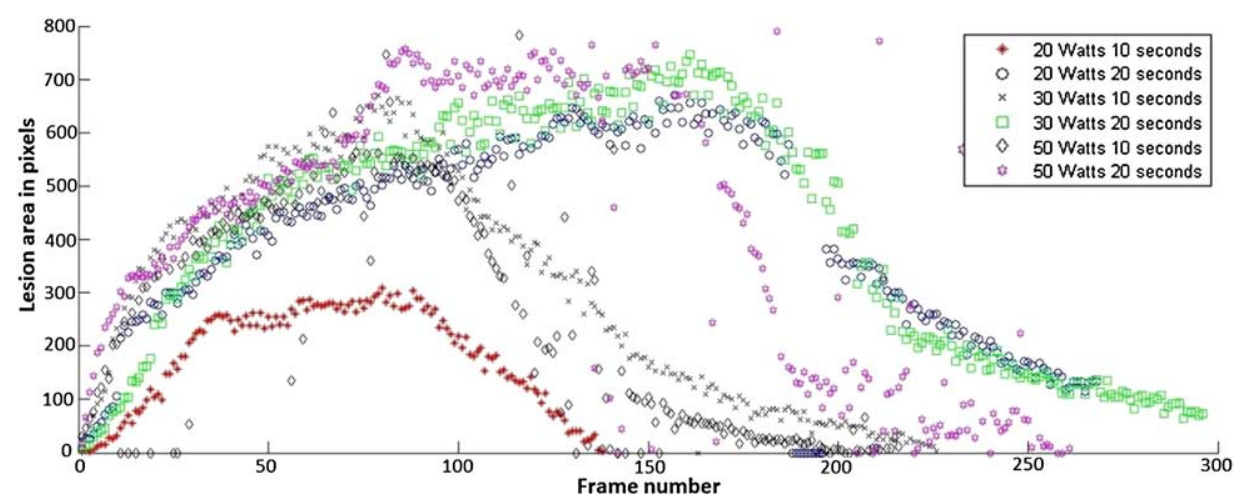

Fig. 6. Dynamics of the pulmonary vein zone lesion area with respect to time.

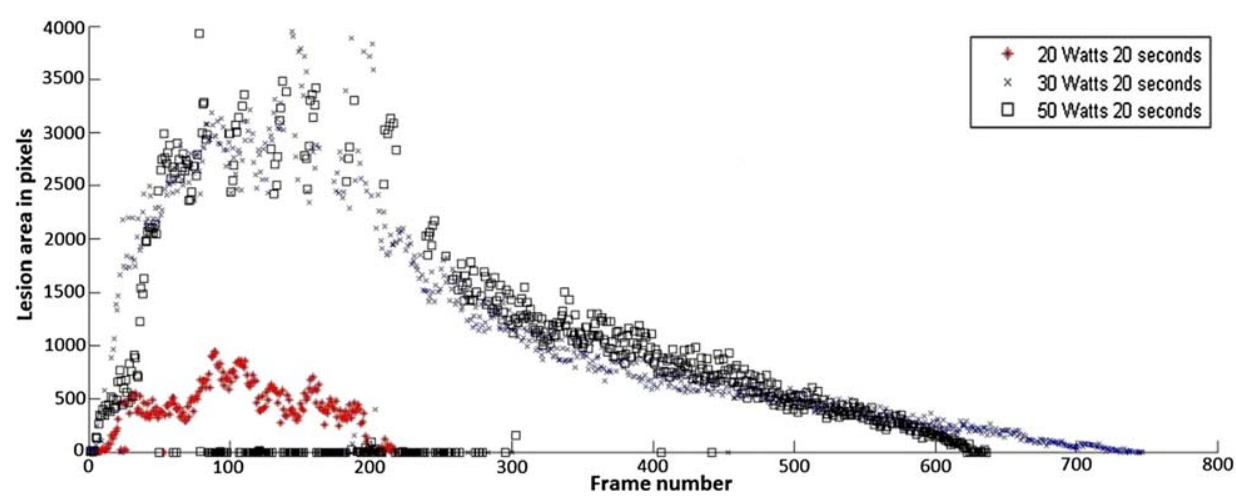

Fig. 7. Dynamics of the atria tissue lesion area with respect to time.

lesion duration. The results are presented in Figs. 6 and 7. In both figures, the lesion area in pixels is presented on the ordinate axis, and footage frames are presented on the abscise axis.

Next, the cone fitting to the data points that represent the lesion area was accomplished. The analysis of the data has showed that it suffices the five-order polynomial to maintain $R^{2}>0.9$ criteria in most cases. $R^{2}$ is a fraction of the variance in the data that is explained by regression. The data for the fitting process were normalized by the mean and standard deviation. If the parametric cone is represented as $y=a x^{5}+b x^{4}+c x^{2}+d x^{2}+e x+f$, then the values for each experiment of the parameters are provided in Tables 3 and 4.

As it can be seen in Fig. 6, dynamics of the anisotropy zone is essentially different from the rest when the zone is operated under the electrode impulse current power of $20 \mathrm{~W}$ and the operation time is set to $10 \mathrm{~s}$. In the case of pulmonary veins anisotropy, where the applied impulse current power outputs of the electrode are 20 and $30 \mathrm{~W}$, respectively, after $20 \mathrm{~s}$ of operation dynamics of the lesion affected area remains almost identical. However, when the electrode impulse current output power is set to $50 \mathrm{~W}$, at 
Table 3

Parameters of the cone for a separate experiment on the pulmonary vein zone

\begin{tabular}{lrrrrrrrr}
\hline $\begin{array}{l}\text { Parameters/ } \\
\text { Experiment }\end{array}$ & \multicolumn{2}{c}{$b$} & \multicolumn{2}{c}{$c$} & $d$ & $e$ & $f$ & $R^{2}$ \\
\hline $20 \mathrm{~W}, 10 \mathrm{~s}$ & 3.23 & 3.85 & -5.56 & -114.8 & -2.04 & 288.2 & 0.96 \\
$20 \mathrm{~W}, 20 \mathrm{~s}$ & 63.37 & 25.11 & -201 & -254.3 & 95.05 & 615 & 0.95 \\
$30 \mathrm{~W}, 10 \mathrm{~s}$ & -26.4 & -12.35 & 219.3 & -96.27 & -437 & 425.6 & 0.98 \\
$30 \mathrm{~W}, 20 \mathrm{~s}$ & 50.65 & 50.61 & -93.08 & -344.4 & -99.3 & 661.3 & 0.95 \\
$50 \mathrm{~W}, 10 \mathrm{~s}$ & -31.1 & 8.87 & 231.9 & -147 & -432 & 398.5 & 0.94 \\
$50 \mathrm{~W}, 20 \mathrm{~s}$ & 88.84 & 102.2 & -243.6 & -481.5 & 11.6 & 734.6 & 0.96 \\
\hline
\end{tabular}

Table 4

Parameters of the cone for a separate experiment on atria

\begin{tabular}{llccccccc}
\hline $\begin{array}{l}\text { Parameters/ } \\
\text { Experiment }\end{array}$ & \multicolumn{2}{c}{$b$} & \multicolumn{2}{l}{$c$} & $d$ & $e$ & $f$ & $R^{2}$ \\
\hline $20 \mathrm{~W}, 20 \mathrm{~s}$ & -15.02 & 3.83 & 60.63 & -234.3 & -62.4 & 630.3 & 0.69 \\
$30 \mathrm{~W}, 20 \mathrm{~s}$ & 269.5 & -423.8 & -577.9 & 21149 & -846 & 756.4 & 0.98 \\
$50 \mathrm{~W}, 20 \mathrm{~s}$ & 253.7 & -294.9 & -567.7 & 22830 & -901 & 1084 & 0.96 \\
\hline
\end{tabular}

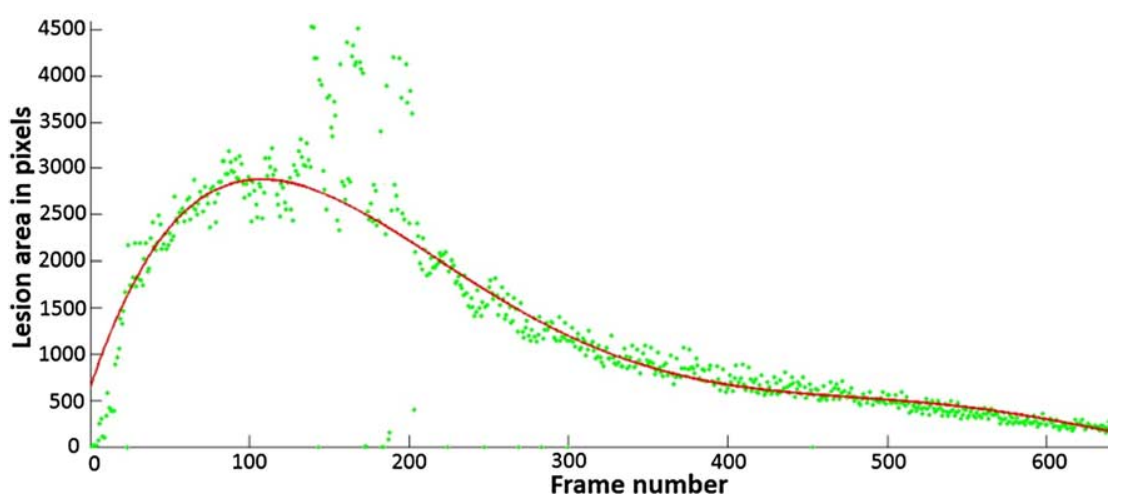

Fig. 8. Data points approximated by a polynomial. Case: atria; parameters: $30 \mathrm{~W}, 20 \mathrm{~s}$.

the beginning the region of lesion spreads likewise that of 20 or $30 \mathrm{~W}$, but the cooling period is much faster. Furthermore, according to the data provided in Fig. 7, the atrium tissue dynamics of the damage area is almost identical when the electrode impulse current output power of 30 and $50 \mathrm{~W}$ was applied, during heating and cooling periods (Figs. 8 and 9). 


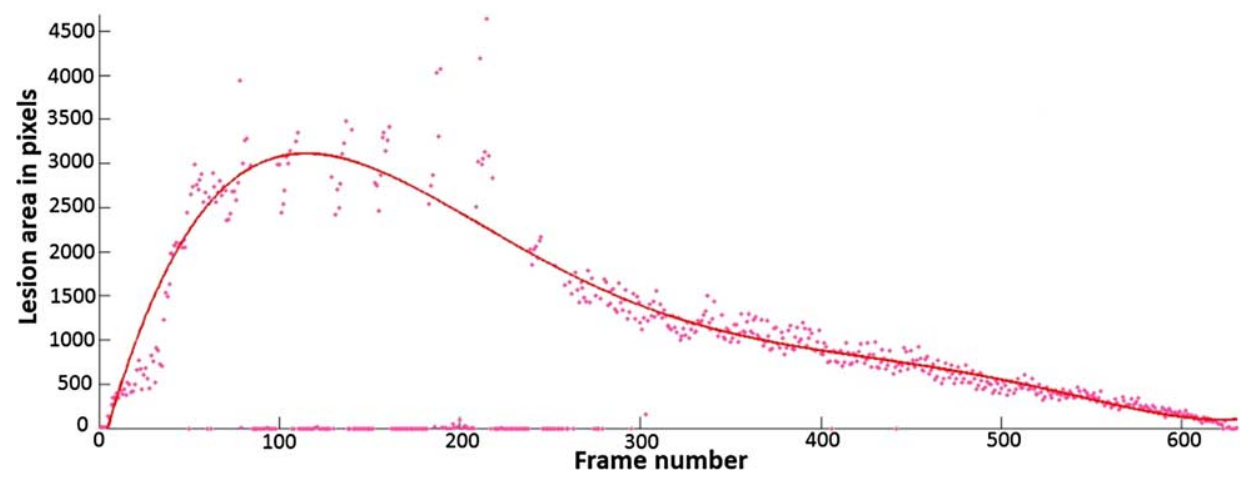

Fig. 9. Data points approximated by a polynomial. Case: atria; parameters: $50 \mathrm{~W}, 20 \mathrm{~s}$.

\section{Investigation of the Nonlinear Pixel Intensities Representation}

By investigating this topic in a broader context, it is not necessary to limit ourselves to the available colour system channels. It is possible to find nonlinear ways for a video signal to be represented as pixel intensities in a spatial domain. A possible nonlinear approach is obtained by using the Lab colour system properties (Russ, 2006). Using this colour system, all pixel intensities can be compared together by Euclidean distances. In this case, the distance can be regarded of as some similarity measure. Suppose that we want to compare the intensity values of all the points, defined in the Lab colour system, with the black point intensity value. To this end, we construct an $n$ by $m$ matrix, where $n$ is the video frame width and $m$ is the video frame height. Each element in the matrix corresponds to the distance between the current point intensity and the black point intensity value. After rearranging the matrix distance values in the interval [0 . 255], it is possible to visualize the image in a spatial domain as the intensity image. Finally, after applying the histogram equalization and automated threshold calculation, the resulting image with separated classes is shown in Fig. 10.

Another experiment was carried out using the method of the principal component analysis. This method was used to find out the correspondence of pixel points with $R, G$, and $B$ components to gray intensity. To achieve this goal, the video stream from the
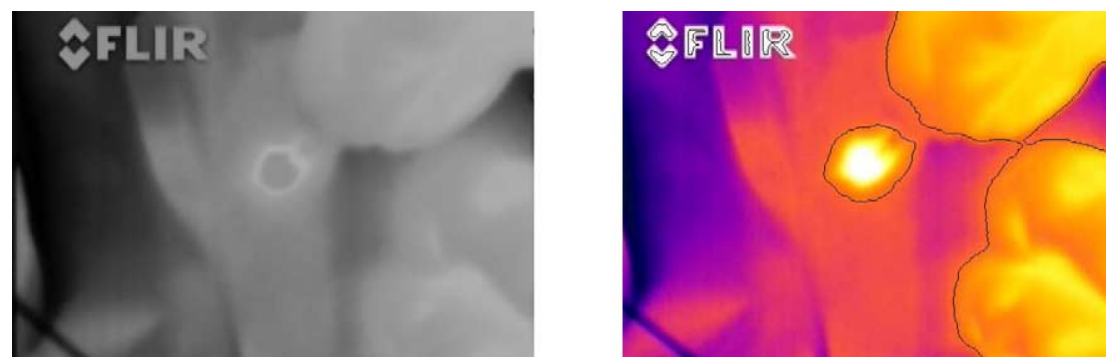

Fig. 10. Euclidean distance matrix as the intensity image (left-hand side), two class separation result in the Euclidean distance matrix (right-hand side). 
thermovision camera was split into frames, then, for each frame, the principal directions of components of all pixels $R, G$, and $B$ were calculated. Next, by selecting the direction with the largest dispersion, we calculate the projection of colour components for each frame pixel in the selected direction. Finally, the calculated projection is rearranged in the interval [0..255]. After the principal component analysis the resulting images as well as the classified image are shown in Fig. 11.

It should be noted that, in this experiment, we did not have a possibility to choose real temperatures from the thermovision camera, only the video footage was taken into consideration. However, the analysis of data in a wider context has revealed that, if we were aware how the thermal camera converts the temperature into colour image, then the temperature could be visualized as an image, thus the problem would remain the same, i.e., to distinguish two classes in the provided image.

The data, got in our study, have showed that the optimal power of RF is $20 \mathrm{~s}$ and $30 \mathrm{~W}$ in the wall of atrium and site of pulmonary veins. Under this condition, we get a homogenous destruction site and configuration. Therefore, there is a minimal damage to neural structures, particularly localised in site of pulmonary veins and arrhythmias related to this site (Batulevičius et al., 2005; Vaitkevičius et al., 2009).

During RF ablation in the tissues of ventricles temperature anisotropy is atypical and not correlating with dotted destructive damage, observed in the manuals of firms that manufacture electrodes or in the methodology of electro-anatomic mapping system images. Our data show that destruction procedures with high power and time application in endocardial or epicardial ventricle's surfaces cause a wide and non-homogeneous damage to tissues, coronary arteries and neural pathways, which leads straight to complications of the procedure.

Usage of thermovision in the experimental study enables us to estimate the peculiarities and borders of the destruction site, to investigate the parameters of RF ablation, which allows us to avoid or minimize undesirable effects, save structures, and improve clinical outcomes.
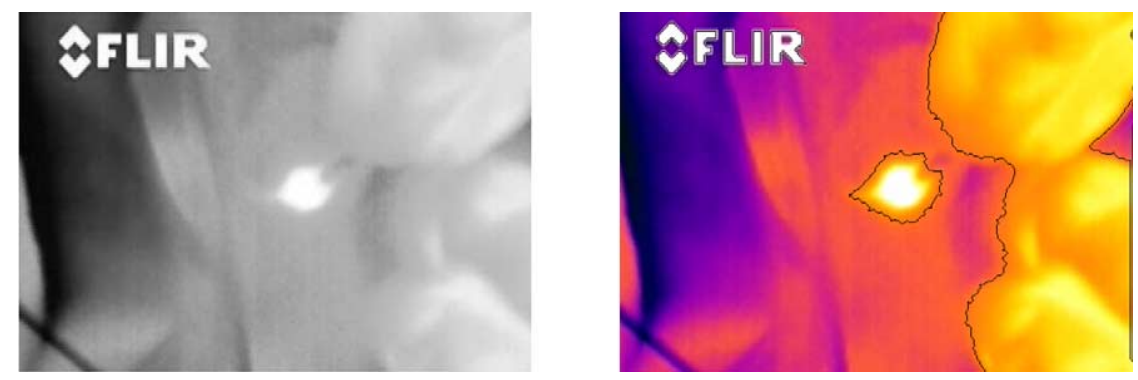

Fig. 11. Image after the principal component analysis (left-hand side), and the classification result (right-hand side). 


\section{Conclusions}

In this article, a method has been proposed for the analysis of the thermovision-based video data that characterizes the heart tissue temperature anisotropy dynamics in a spatial domain.

The analysis of spread of the risk area, made according to the electrode ablation impulse current power and time, has showed that the tissue thermal anisotropy dynamics remains almost the same during heating and cooling stages, regarding to 30 and $50 \mathrm{~W}$ power and $20 \mathrm{~s}$ lesion time settings on the atria tissue.

The analysis of the principal components as well as of vector lengths has proved that the problem of unknown temperatures can be reduced to that of separating two classes, no matter how the initial colour system pixel intensities are mapped into the gray level intensity interval.

The method proposed for thermovisual data processing lets us measure and record the tissue temperature changes. This, in turn, allows the real time control of destruction boundaries of the tissue in order to avoid adverse effects and preserve the structures in which the damage would have injurious consequences.

Unlike other methods of visualization, thermography can be easy applied without requiring special precautions of foreign contrast agents, and it renders the heart free for surgical procedures throughout the imaging process. Real-time scanning at standard video rates enables to see rapid, thermally transient events, gives an opportunity to visualize temperature dynamics on the beating heart and by this assess myocardium function.

Acknowledgement. The research is partially supported by the Lithuanian State Science and Studies Foundation project "Development of special data mining methods to explore the anisotropy of texture's temperatures of the heart," No. T-08153. In addition, we would like to express thanks to company "Elintos Matavimo Sistemos" for providing the thermovision camera.

\section{References}

Aupperle, H., Doll, N., Walther, T., Ullmann, C., Schoon, H.A., Mohr, W.F. (2005). Histological findings induced by different energy sources in experimental atrial ablation in sheep. Interactive CardioVascular and Thoracic Surgery, 4(5), 450-455.

Batulevičius, D., Skripka, V., Pauzienè, N., et al. (2005). Topography of the porcine epicardiac nerve plexus as revealed by histochemistry for acetylcholinesterase. Annals of Anatomy, 187(3), 225-243.

Berruezo, A., Tamborero, D., Mont, L., Benito, B., Tolosana, J.M., Sitges M., et al. (2007). Pre-procedural predictors of atrial fibrillation recurrence after circumferential pulmonary vein ablation. European Heart Journal, 28, 836-841.

Chien, K.R. (2000). Genomic circuits and the integrative biology of cardiac diseases. Nature, 407(6801), 227232.

Dzemyda, G., Veikutis, V., Jakuška, P., Puodžiukynas, A., Treigys, P., Medvedev, V. (2008). Development of special data mining methods to explore the anisotropy of texture's temperatures of the heart. Report for project No. T-08153. Vinius, Institute of Informatics and Mathematics (in Lithuanian).

Hunt, R.W., Horwood, E. (1998). Measuring Colour, 3rd ed. Fountain Press, New York. 
Jais, P., Hocini, M., Hsu, L.F., Sanders, P., Scavee, C., Weerasooriya, R., et al. (2004). Technique and results of linear ablation at the mitral isthmus. Circulation, 110, 2996-3002.

Jiying, W., Qiuqi R., Gaoyun A. (2010). Exemplar-based image completion model employing PDE corrections. Informatica, 21(2), 259-276.

Lekas, R., Jakuška, P., Kriščiukaitis, A., Veikutis, V., Dzemyda, G., Mickevičius, T., Morkūnaitè, K., Vilkè, A., Treigys, P., Civinskienė, G., Andriuškevičius, J., Vanagas, T., Skauminas, K., Bernatonienė, J. (2009). Monitoring changes in heart tissue temperature and evaluation of graft function after coronary artery bypass grafting surgery. Medicina, 45(3), 221-225.

Mačiulis, A., Paunksnis, A., Barzdžiukas, V., Kriaučiūniené, L., Buteikienė, D., Puziené, V. (2009). Digital model of blood circulation analysis system. Informatica, 20(4), 539-554.

Ouyang, F., Bansch, D., Ernst, S., Schaumann, A., Hachiya, H., Chen, M., Chun, M., Falk, P., Khenedani, A., Antz, M., Kuck, K.H. (2004). Complete isolation of left atrium surrounding the pulmonary veins: new insights from the double-Lasso technique in paroxysmal atrial fibrillation. Circulation, 110, 2090-2096.

Pappone, C., Oreto, G., Rosanio, S., Vicedomini, G., Tocchi, M., Gugliotta, F., et al. (2001). Atrial electroanatomic remodeling after circumferential radiofrequency pulmonary vein ablation: efficacy of an anatomic approach in a large cohort of patients with atrial fibrillation. Circulation, 104, 2539-2544.

Qian, L.J., Cheng, S.Q., Wu, M.P. (1999). Changes of mitochondrial function in heat stressed rats. Chin. J. Pathol. Physiol., 15, 333-335.

Rencz, A.N. (1999). Remote Sensing for the Earth Sciences, 3rd ed. Wiley, Hoboken.

Russ, J.C. (2006). The Image Processing Handbook. CRC Press, Boca Raton.

Shanker, S. (2001). What children know when they know what a name is: the non-cartesian view of language acquisition, Current Anthropology, 42(4), 481-513.

Sminia, P., van der Zee, J., Wondergem, J., Haveman, J. (1994). Effect of hyperthermia on the central nervous system: a review. International Journal of Hyperthermia, 10(1), 1-30.

Song, X.L., Qian, L.J., Li, F.Z. (2000). Injury of heat stress on rat cardiomyocytes. Chin. J. Appl. Physiol., 16, $227-230$.

Steenland, K. (1996). Epidemiology of occupation and coronary heart disease: research agenda. American Journal of Industrial Medicine, 30(4), 495-499.

Tan, E.S., Mulder, B.A., Rienstra, M., Wiesfeld, A.C.P., Ahmed, S., Zijlstra, F., van Gelder, I.C. (2009). Pulmonary vein isolation of symptomatic refractory paroxysmal and persistent atrial fibrillation. Netherlands Heart Journal, 17(10), 366-372.

Tian, H., Lam, S.K., Srikanthan, T. (2003). Implementing Otsu's thresholding process using area-time efficient logarithmic approximation unit. In: IEEE International Symposium on Circuits and Systems (ISCAS), Vol. 4. Bangkok, Thailand, pp. 21-24.

Treigys, P. (2010). Development and Application of Methods in the Graphical Ophthalmological and Thermovisual Data Analysis. PhD thesis. Vilnius.

Treigys, P., Šaltenis, V., Dzemyda, G., Barzdžiukas, V., Paunksnis, A. (2008). Automated optic nerve disc parameterization. Informatica, 19(3), 403-420.

Vaitkevičius, R., Saburkina, I., Rysevaite, K., et al. (2009). Nerve supply of the human pulmonary veins: an anatomical study. Heart Rhythm, 6(2), 221-228.

Wondergem, J., Haveman, J., Rusman, V., Sminia, P., Van Dijk, J.D.P. (1988). Effects of local hyperthermia on the motor function of the rat sciatic nerve. International Journal of Radiation Biology, 53(3), 429-438.

V. Veikutis graduated from the Kaunas Medical Institute, Lithuania, in 1979. In 1982 started science studies in Central Research Laboratory of Kaunas Medical Institute, Laboratory of Cardiac Arrhythmia Disturbancies Surgery, when in 1989 received doctoral degree in medical sciences. He was conferred the title of assoc. professor at Kaunas University of Medicine. Now he is head of Laboratory of Electrophysiology, Institute for Biomedical Research of Kaunas University of Medicine. His interests include cardiac arrhythmia and cardiac innervations investigation; possibilities apply thermovision methodology to clinical practice. 
G. Dzemyda graduated from the Kaunas University of Technology, Lithuania, in 1980, and in 1984 received there the doctoral degree in technical sciences $(\mathrm{PhD})$ after postgraduate studies at the Institute of Mathematics and Informatics, Vilnius, Lithuania. In 1997, he received the degree of doctor habilius from Kaunas University of Technology. He was conferred the title of professor (1998) at the Kaunas University of Technology. He is director of the Institute of Mathematics and Informatics and heads the System Analysis Department of the institute. The areas of research are the theory, development and application of optimization, and the interaction of optimization and data analysis. His interests include optimization theory and applications, data mining in databases, multiple criteria decision support, artificial neural networks, parallel optimization, multidimensional data visualization.

P. Treigys graduated from the Vilnius Gediminas Technical University, Lithuania, in 2005. In 2010 received the doctoral degree in technical sciences $(\mathrm{PhD})$ at the Institute of Mathematics and Informatics. He is a lecturer at the Vilnius College of Higher Education. He is a member of the Lithuanian Society for Biomedical Engineering. His interests include: image analysis, detection and objectæs feature extraction in image processing, automated image objects segmentation, optimization methods, artificial neural networks, software engineering.

K. Morkūnaitė graduated from Kaunas University of Medicine, Lithuania, in 2007. Now she is 3th year cardiology resident in Department of Cardiology, Kaunas University Clinical Hospital. In addition, she is junior research worker, Institute of Cardiology. Research interests include cardiac arrhythmia and cardiac innervation investigation.

A. Basevičius graduated from Kaunas Medical Institute, Lithuania, in 1986. In 1992 received the doctoral degree in medicine, Kaunas Medical Academy. Assoc. professor, head of Dept. of Radiology of Kaunas University Clinical Hospital.

S. Lukoševičius graduated Kaunas Medical Academy (at present Kaunas University of Medicine), Lithuania, in 1995. Doctoral degree (2002), assoc. professor, Dept. of Radiology, Kaunas University of Medicine, chairman of Section of Tomographies. Research interest include cerebral computed tomography angiography in the event of subarachnoid hemorrhage.

A. Sederevičius graduated Lithuanian Veterinary Academy in 1974. In 1983 received doctoral degree in biology, Institute of Physiology and Biochemistry of Agricultural Animals Scientific Studies of Ukraine. Professor in Lithuanian Veterinary Academy, 2005. Research interest include graphic representation of physiological processes of animals' organism.

G. Šakalytė graduated from Kaunas Medical Institute, Lithuania, in 1989. Cardiologist in Departament of Cardiology of Kaunas University of Medicine Clinical Hospital, scientific researcher in Institute of Cardiology, assoc. professor at Kaunas University of Medicine, 2008. Field of interest: arterial hypertension and drug therapy - effect on the rest and exercise blood pressure; ischemic heart disease: long term prognosis of invasive and non-invasive treatment; heart failure treatment and prognosis. 


\section{Radijo dažniu itakos miokardo pažaidai termoviziniu duomenu analizè}

Vincentas VEIKUTIS, Gintautas DZEMYDA, Povilas TREIGYS, Kristina MORKŪNAITÉ, Algidas BASEVIČIUS, Saulius LUKOŠEVIČIUS, Gintare ŠAKALYTĖ, Antanas SEDEREVIČIUS

Šiame straipsnyje yra pateikiama termovizinių vaizdinių duomenų charakterizuojančių temperatūrinę širdies audinio anizotropiją dinamikos analizė vaizdineje srityje. Daugelis širdies sutrikimu paprastai yra gydomi naudojant destrukcinius energijos šaltinius. Viena iš labiausiai paplitusių metodiku yra susijusi su radijo dažninèmis abliacijomis. Tačiau, naudojant šią metodiką komplikaciju, iskaitant ir ligos atsinaujinimą, rizika išlieka didelè. Problema yra ta, kad naudojama metodika remiasi audinio šiluminio laidumo savybèmis, kurios tiesiogiai negali būti suvokiamos regos organais. Taigi, siekiant ištirti pooperaciniu komplikaciju prigimtị bei galimai sumažinti ju kiekị, būtina ištirti širdies audinio reakciją ị kaitinima, atsižvelgiant i elektrodo impulsinès srovès galios ir laiko parametrus, tam pasitelkus termovizijos priemones ir vaizdų analizès metodu teikiamas galimybes. 